\title{
Present and Future Desertification in the Iberian Peninsula
}

\author{
Alfredo Rocha*, Susana C. Pereira, Carolina Viceto and Rui Silva \\ CESAM-Department of Physics, University of Aveiro, Portugal
}

Submission: May 22, 2019; Published: June 03, 2019

*Corresponding author: Alfredo Rocha, Department of Physics, University of Aveiro, Campus Universitário de Santiago, 3810 -193 Aveiro, Portugal

Keywords: Iberian Peninsula; Rainfall; Precipitation; Atmospheric conditions; Desertification

\section{Short Communication}

The Iberian Peninsula (IP) is experiencing desertification as a result of climate change caused by increasing human greenhouse gas emission [1]. This is particularly relevant in its southern regions where the average annual precipitation can be as low as $200 \mathrm{~mm}$.

Rainfall has decreased in the region and this trend is expected to persist [2-4]. Many studies identify a small, nonsignificant, increase in winter precipitation and significant precipitation reductions in the other seasons by 2100 , under the RCP8.5 scenario [5-8].

Pereira et al. [9] detail the behaviour of precipitation and its changes in the IP and refer that, by 2100 , for the RCP8.5, most of the region is expected to experience a statistically significant $20-30 \%$ reduction in precipitation which would contribute to desertification already occurring in some southern regions [10]. The exception is for winter where a small and not significant increase is projected. For summer, their study indicates a larger precipitation reduction of about $60 \%$ in a season where precipitation is already scarce and may pose problems for water resources. Intermediate seasons (MAM and SON) likewise experience precipitation reduction. Pereira et al. [9] further evaluate the full range (duration/intensity) of high frequency episodes and report a marked reduction in the average number of days of all-type precipitation episodes in the future. The combined effects of reduced precipitation and less precipitation days represent a generalized future tendency for precipitation to occur more concentrated in time in short-lived extreme precipitation episodes that, through extensive runoff, may generate landslides and flash-floods/floods, which can disrupt social and economic activities.
Viceto et al. [11] point to future increases in the number of atmospheric conditions favourable to severe storms associated to higher Convective Available Potential Energy in the region, particularly in the Mediterranean. These findings appear to agree with results of Pereira et al. [9] since the nature of precipitation in the IP seems to be become more of a convective nature in the future.

Changes in precipitation are accompanied with extensive future warming as reported by Viceto et al. [12]. The projected temperatures show an increase of over $6^{\circ} \mathrm{C}$ in some southern regions by 2100 , concomitant with highest numbers of summer days and tropical nights. The number of heat wave days are expected to increase, with much of the average summer season being under heat wave conditions. Central/southern IP may experience an average of between 20 heat wave days per year with maximum temperatures surpassing $45^{\circ} \mathrm{C}$ in each wave day. For some locations in the southern/central non-costal region heat waves may last nearly the whole summer, with average maximum temperatures of about $40^{\circ} \mathrm{C}$.

The combined changes of precipitation and temperature may have disastrous impacts in water resources, namely agriculture, and desertification than those associated to each variable independently. Figure 1 shows temperature and precipitation changes for Alentejo (Portugal) between 1971-2000 and 20712100 , for the RCP8.5 scenario. Each dot represents one year of the ensemble average of a set of CORDEX regional climate model simulations performed on the European domain (EUROCORDEX) at spatial resolution of 0.11 degree $(\sim 12 \mathrm{~km})$. The black dots represent the climate averages. Alentejo is one of the regions under a desertification process and is considered here to illustrate the dramatic changes many similar southern regions of the IP are expected to experience in the future. 


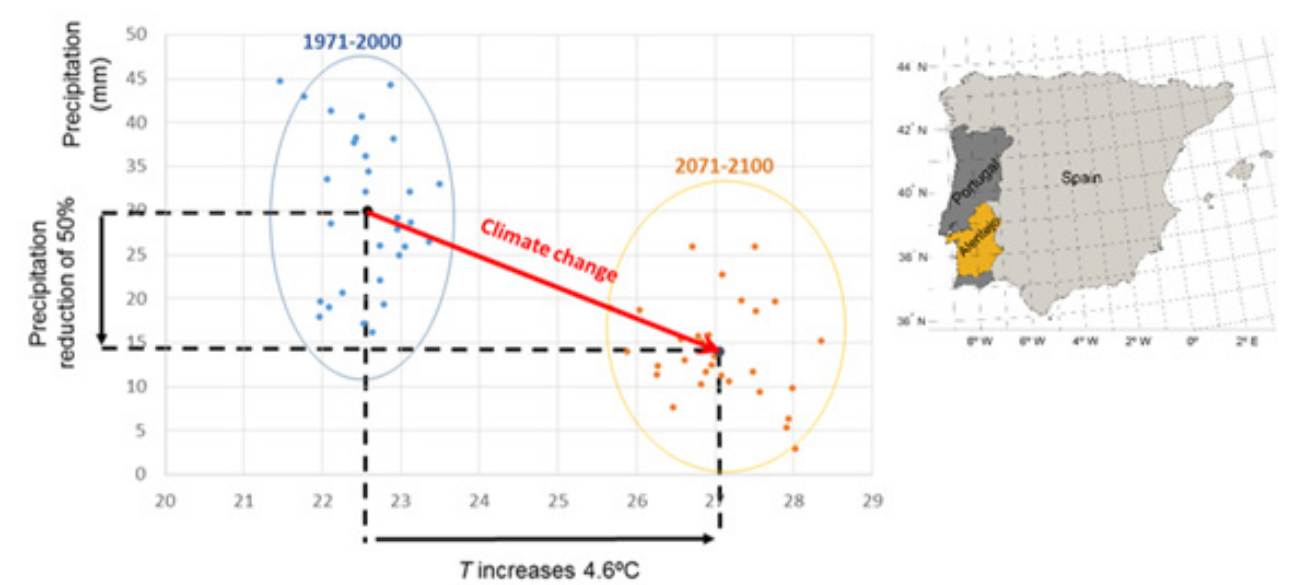

Figure 1: Temperature and precipitation changes for Alentejo (Portugal) between 1971-2000 and 2071-2100, for the RCP8.5 scenario. Each dot represents 1 year of the ensemble average of a set of CORDEX regional climate model simulations performed on the European domain (EURO-CORDEX) at spatial resolution of 0.11 degree $(\sim 12 \mathrm{~km})$. Data and detail of models and simulations can be found in http:// portaldoclima.pt/pt/

\section{References}

1. Guerreiro S, Kilsby C, Fowler J (2017) Assessing the threat of future megadrought in Iberia. Int J Climatol 37(15): 5024-5034.

2. Gonzalez-Hidalgo JC, Brunetti M, De Luis M (2010) Precipitation trends in Spanish Hydrological Divisions, 1946-2005. Clim Res 43(3): 215-228.

3. Karagiannidis AF, Karacostas T, Maheras P, Makrogiannis T (2012) Climatological aspects of extreme precipitation in Europe, related to mid-latitude cyclonic systems. Theor Appl Climatol 107(1-2): 165-174.

4. de Lima MIP, Santo FE, Ramos AM, Trigo RM (2014) Trends and correlations in annual extreme precipitation indices for mainland Portugal, 1941-2007. Theoretical and Applied Climatology 119(1-2): 55-75.

5. Casanueva A, Rodríguez-Puebla C, Frías MD, González-Reviriego N (2014) Variability of extreme precipitation over Europe and its relationships with teleconnection patterns. Hydrology and Earth

6. Costa AC, Santos JA, Pinto JG (2012) Climate change scenarios for precipitation extremes in Portugal. Theoretical and Applied Climatology 108(1-2): 217-234.
7. Rajczak J, Schär C (2017) Projections of Future Precipitation Extremes Over Europe: A Multimodel Assessment of Climate Simulations. J of Geophys Res Atmospheres 122(20): 10,773-10,800.

8. Soares PMM, Cardoso RM, Lima DCA, Miranda PMA (2017) Future precipitation in Portugal: high-resolution projections using WRF model and EURO-CORDEX multi-model ensembles. Clim Dyn 49(7-8): $2503-2530$

9. Pereira SC, Marta-Almeida M, Carvalho AC, Rocha A (2019) Extreme Precipitation Events under Climate Change in the Iberian Peninsula. Int J Climatol (in press).

10. Fernández-González S, Del Río S, Castro A, Penas A, FernándezRaga M, et al. (2012) Connection between NAO, weather types and precipitation in León, Spain (1948-2008). International Journal of Climatology 32(14): 2181-2196.

11. Viceto C, Marta-Almeida M, Rocha A (2017) Future climate change of stability indices for the Iberian Peninsula. Int J of Climatol 37(12): 4390-4408.

12. Viceto C, Marta-Almeida M, Rocha A (2019) Climate Change Projections of Extreme Temperatures for the Iberian Peninsula. Atmosphere 10(5): 229.

\section{Your next submission with Juniper Publishers will reach you the below assets}

- Quality Editorial service

- Swift Peer Review

- Reprints availability

- E-prints Service

- Manuscript Podcast for convenient understanding

- Global attainment for your research

- Manuscript accessibility in different formats ( Pdf, E-pub, Full Text, Audio)

- Unceasing customer service

Track the below URL for one-step submission https://juniperpublishers.com/online-submission.php 